\title{
Well Log Petrophysics of the Cretaceous Pay Zones in Zubair Field, Basrah, South Iraq
}

\author{
Abdulaziz M. Abdulaziz*, Abdel Sattar A. Dahab, Mohammed Y. Najmuddin \\ Faculty of Engineering, Cairo University, Giza, Egypt \\ Email: *amabdul@miners.utep.edu
}

How to cite this paper: Abdulaziz, A.M., Dahab, A.S.A. and Najmuddin, M.Y. (2017) Well Log Petrophysics of the Cretaceous Pay Zones in Zubair Field, Basrah, South Iraq. Open Journal of Geology, 7, 1552-1568. https://doi.org/10.4236/ojg.2017.710104

Received: August 29, 2017

Accepted: October 28, 2017

Published: October 31, 2017

Copyright $\odot 2017$ by authors and Scientific Research Publishing Inc. This work is licensed under the Creative Commons Attribution International License (CC BY 4.0).

http://creativecommons.org/licenses/by/4.0/

\begin{abstract}
Discovered in 1949 with a rate of $(195,000)$ bbl/day from pay zones in Mishrif and Zubair Formation, the expected production of Zubair field is anticipated to be 1125 million bbl/day. Despite this production history, there is a major deficiency in detailed petrophysical analysis of the producing zones. In the present study well log data of 7 wells, selected from numerous wells, are investigated in details to examine the reservoir properties and characterize the reservoir architecture. The petrophysical analysis of Mishrif Formation indicated two or three pay zones. Lithologically, all zones of Mishrif Formation are dominantly clean limestone to dolomitic limestone with zone 2 and 3 reporting higher dolomitic content (20\% to $40 \%$ ) compared to zone 1 ( $6 \%$ to $13 \%)$. Mishrif pay zones indicated a relatively good porosity $(18 \%-24 \%)$ with zone 2 predominant in secondary porosity associating dolomitization processes. In Zubair Formation one pay zone is identified but locally could separate into two zones. The clay content is generally low with average content between $2 \%$ and $3 \%$ while the average porosity showed slightly better values in zone $1(\sim 0.20)$ compared to average porosity of zone $2(0.17)$ that is rich in silt content associating deposition at a relatively deeper parts of the shelf. The average water saturation shows distinct lower values that vary between $15 \%$ and $18.7 \%$. The petrophysical results are statistically analyzed and property histograms and crossplots are constructed to investigate mutual relationships. Such analysis is essential for understanding the reservoir architecture and calculations of reservoir capacity for future development.
\end{abstract}

\section{Keywords}

Petrophysical Analysis, Zubair Field, Mishrif Formation, Zubair Formation, Reservoir Characterization

\section{Introduction}

Differences in petrophysical characteristics observed in petroleum reservoir 
around the world are important for reservoir evaluation and must be well understood. This requires the conjugated efforts of geoscientists and engineers in a multi-disciplinary synergistic approach to recognize the complex variations in reservoir heterogeneity and its associating hydraulic properties [1]. Such synergistic approach is discussed by Harris et al. in [2] and emphasized the importance of geological and engineering approaches for reservoir characterization. Integration of well logs with core data is a typical characterization approach that has been discussed by numerous formation evaluation works (e.g. [3]), but the output of such research did not provide characteristics such as flow units identification and macroscopic geologic and/or petrophysical features integratable to reservoir flow models or simulation studies. Core samples are the only representative physical element of the reservoir rock available for examination and inconsequence represent the fundamental source for reservoir description on both microscopic (pore level) and macroscopic (core plug) levels. Alternatively, well logs, wireline tests, and well tests develop megascopic reservoir properties in form of moving averages with windows vary based on the individual log resolution. Worthington and Cosentino in [4] presented the effect of cutoffs value on integrated reservoir studies and highlighted the importance of petrophysical cutoffs on reservoir characterization for both static and dynamic models that inconsequence lead to realizations of the asset value.

Southeastern Iraq represents a high hydrocarbon potential region with several high productivity fields have been discovered. The bulk Iraqi oil reserve is generally found in two distinct basins; Zagros basin and Arabian basin [5]. Discovered in 1949, Zubair field represents one of the largest oil fields in the world with 4.5 billion barrels $(\sim 6.1 \times 108 \mathrm{t})$ proven reserves. At early reservoir stages production began with $195,000 \mathrm{bbl} /$ day, but by $2010-2011$ reached 300,000 bbl/day and is expected to reach 1125 million bbl/day [6]. Recently a substantial increase in estimations of Zubair field proven reserve has been reported as 7.8 billion bbl [6]. It is located in Southeastern Iraq to the Southwest of Basrah city with oil bearing zones fall within two main Cretaceous successions: Upper Cretaceous Mishrif Formation and the Lower Cretaceous Zubair Formation. Zubair Formation is the most significant clastic reservoir in Southern Iraq and constitutes approximately $30 \%$ of hydrocarbon reserve in Iraq. Significant hydrocarbon accumulations are trapped within 30 geologic structures developed within important producing fields including East Baghdad, Zubair, and Rumaila (north \& south). Alternatively, Zubair Formation furnishes a secondary target at Ratawi, Tuba, and Luhais fields but at Majnoon, Huwaiza, and Halfaya contains only smaller reserves [6]. The sandstone reservoir quality of Zubair Formation is generally good with porosity between 15\% near Iraqi border and 30\% in Salman Zone to the West [7].

Mishrif Formation comprises approximately $40 \%$ of Cretaceous hydrocarbon reserve that constitutes $30 \%$ of the total Iraqi reserve [8]. Important oil accumulations are trapped on large scale north-south trending anticlines as reported at 
North Rumaila, South Rumaila, Zubair, West Qurna, Halfaya and Majnoon fields [7]. In addition, other commercial oil accumulations, at least 15, have been discovered in the Mishrif Formation in Southeastern Iraq; e.g. Abu Ghurab, Dujaila, Jebel Fauqi, Kumait, Noor, Rafidain, Tuba, NahrUmr, and others. It reported mean porosities of $16 \%$ at Rumaila and $9 \%$ at Zubair fields but well developed reservoir quality with porosity up to $36 \%$ and average permeability 1560 $\mathrm{mD}$ is observed in rudist-rich carbonates [9]. Reulet in [10] summarized the average values of porosity and permeability for Mishrif facies in Southern Iraq and showed that shoal facies has higher porosity that ranged between $20-25 \%$. However, reservoir quality decreases significantly southwest toward the Najaf intra-shelf basin with massive reservoir along the Iraqi-Iranian border [6]. Due to the promising potential of the producing zones in Zubair field, petrophysics of these zones need to be well characterized. In the present study, petrophysical characteristics of the pay zones in Zubair field are analyzed using available well log data. This encompasses detailed well log analysis to accurately identify the potential of hydrocarbon zones and develop detailed reservoir characteristics.

\section{Geological Setting}

The geology of Zubair field is best described in the context of the geology of Mesopotamian Basin (Figure 1). Detailed geological and tectonic framework of Mesopotamian Basin have been described in literature (e.g. [11] [12] [13]) with three important subzones identified; Tikrit-Amara, Samawa-Nasiriya, and Zubair. The main lithostratigraphic units of South Iraq is presented in the composite stratigraphic column shown in Figure 2.

Generally, the hydrocarbon production is concentrated within the New Tethys Extension tectonics (Figure 2); however Zubair and Mishrif Formation remain the most producing intervals [14]. Mishrif Formation and the conformably underlying Rumaila Formation are first described at Zubair field where Mishrif Formation showed a gradual contact with both Rumaila and Kifil Formation. In parts where Kifil Formation is absent Mishrif Formation is marked by an unconformity (Figure 2). Mishrif Formation comprises Mid-Cenomanian to Early Turonian extensive carbonate platform that prevails Southern Iraq and extends eastward to Iran (Upper Sarvak Formation) and southeast to Oman (Natih A-C members of Natih Formation) [15]. It is heterogeneous detrital calcareous sediments that involve rudist, algal, and coral reef limestone with rare shale intercalations and predominantly covered by fresh water limonitic limestone [16] [17]. In Zubair field, Mishrif Formation is made of gray dense algal limestone with shelly foraminiferal limestone rich in rudist debris at the bottom and gastropods to shell fragments at the top [18]. Stratigraphically, Mishrif Formation presents a regressive sequence (Figure 3 ) of two sub-cycles: the early sub-cycle extends between the outer-shelf open marine and the limited lagoonal condition, while the late sub-cycle done by discontinuous sediments [10] [16]. The thickness of Mishrif 


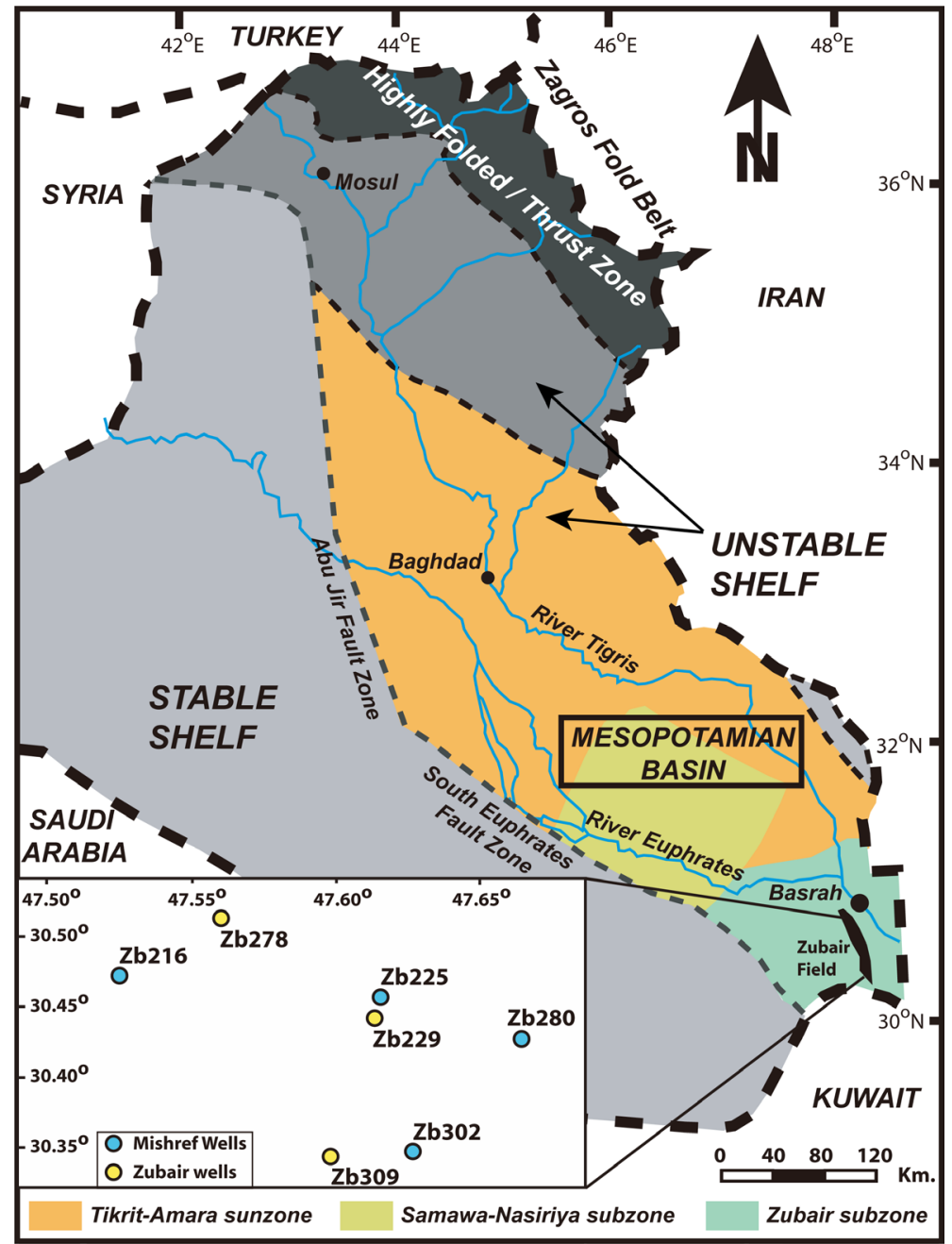

Figure 1. The geology of Zubair field in context of the Mesopotamian Basin showing a location map for the studied wells (modified from [11] [12] [13]).

Formation varies dramatically through the Mesopotamian Basin with 350 - 400 $\mathrm{m}$ in SE boundary (270 $\mathrm{m}$ Zubair field) and pinches out towards the West and SW [19]. Developed on 32 geologic structures, petroleum plays in Mishrif Formation typically occupy a relatively narrow NW-SE belt across central and Southeastern Iraq [20].

Zubair Formation involves 380 - $400 \mathrm{~m}$ succession of shale and sandstone with siltstone intercalations deposited in a littoral, partly deltaic environment (Figure 3) that started as regressive phases of prodelta, delta front, marsh and swamp and ended as a shelf [21]. It shows in most cases gradational and conformable contacts to the upper and lower Formation (Figure 2 and Figure 3). At Zubair field, Zubair Formation reports $200 \mathrm{~m}$ thick of net sand that decreases gradually and completely disappear at Iran border. Generally, the reserve of South Iraq oil fields is originated from source rocks in the Arabian basin [7]. Al Rawi in [22] proved the prospectivity of sandstone members in Zubair Formation and showed that the total organic carbon between $1 \%$ and $24 \%$ in thin marine shale 


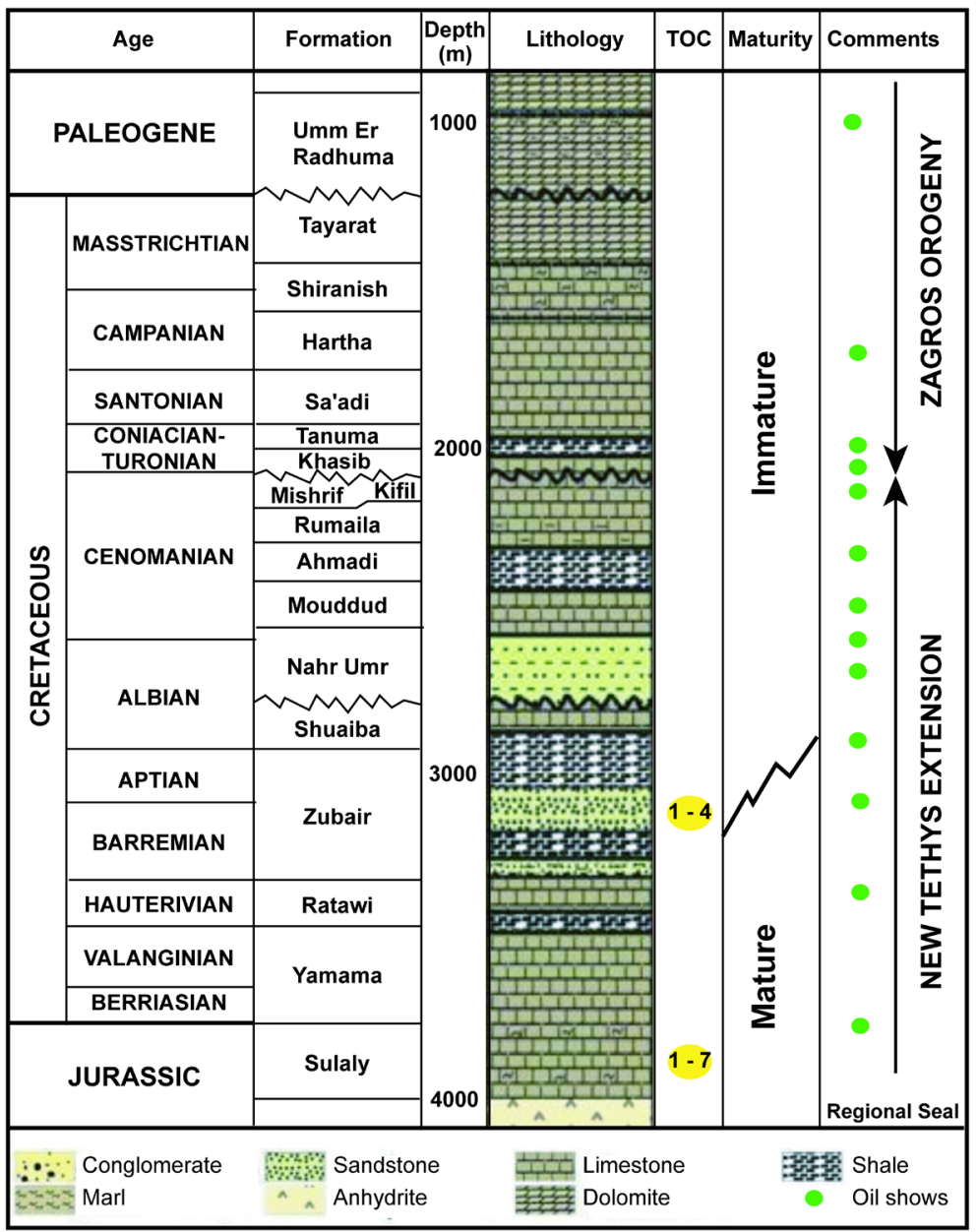

Figure 2. A composite stratigraphic column showing the main lithostratigraphic units of South Iraq (modified from [14]).

indicates deposition in the prodelta zone of offshore facies. Owen and Nasser in [23] identified five members in Zubair Formation (upper shale, upper sand, middle shale, lower sand, and lower shale) that seem identical at Zubair area and typically show different apparent thickness (Table 1). These members act as source and reservoir units but occasionally develop potential seal. Within Southern Rumailah Oil field, Al-Jubory in [24] recognized four sedimentary facies in the upper Zubair sand member including channel, swamp and marshes, distributary mouth bar, and prodelta facies (Figure 3).

\section{Methods}

To delineate the main reservoir characteristics, a suite of well log readings from numerous wells drilled in Zubair field, both analogue and digital format, are visually evaluated. Of these data, seven sets of well logs are selected for detailed analysis in the present study (Figure 1). Ideally digital well logs are directly used in analysis while paper logs are scanned and digitized to be compatible with other digital dataset. Subsequently, all data set are reviewed, edited, and in some 


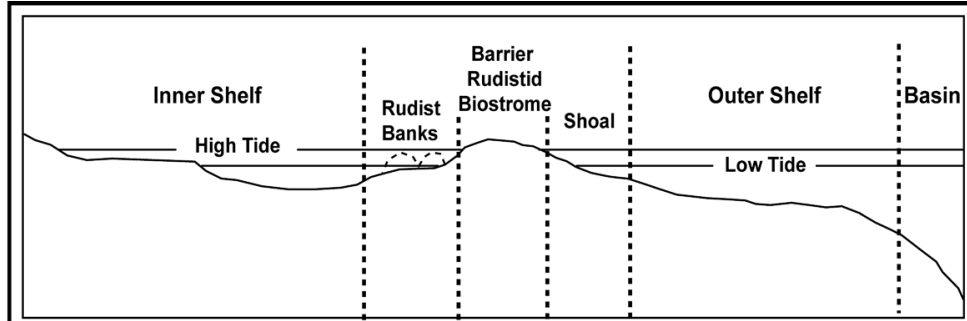

Depositional Setting of the Middle Cretaceous Mishrif Formation in Southern Iraq.

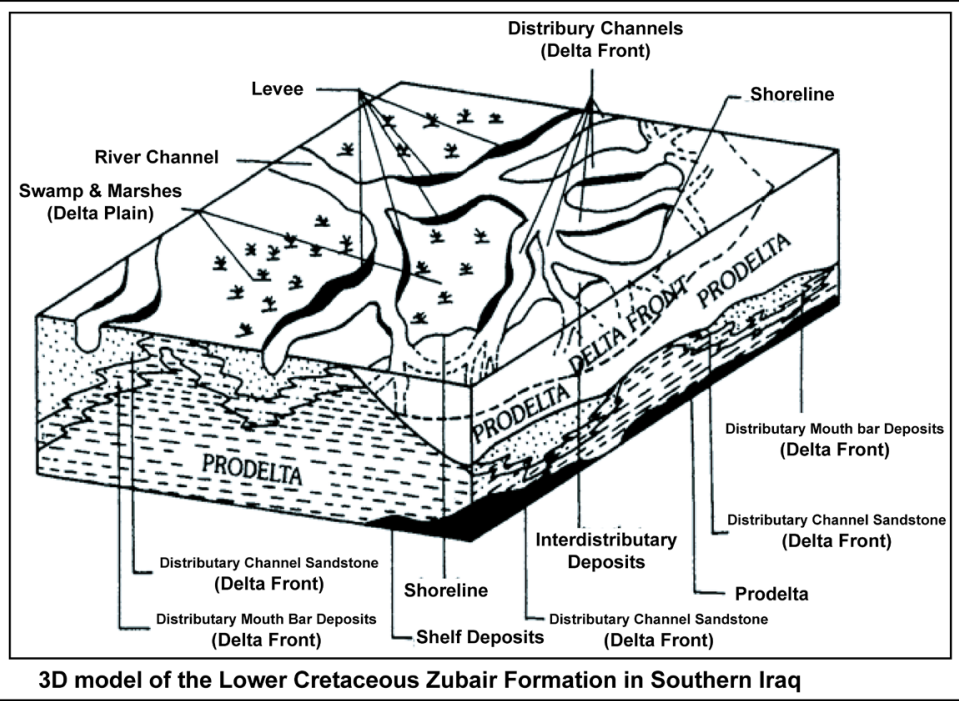

Figure 3. Depositional setting of Mishrif Formation adapted from [10] (upper) and 3D model of the Lower Cretaceous Zubair Formation in Southern Iraq from [21], (lower).

Table 1. The five members of Zubair Formation identified by Owen and Nasser in [21] in Zubair Field, South Iraq.

\begin{tabular}{|c|c|}
\hline Members & Lithological Description \\
\hline Upper Shale & Greenish black shale encompassing a sandstone-siltstone. \\
\hline Upper Sandstone & Mainly sandstone with subordinate siltstone. \\
\hline Middle Shale & $\begin{array}{l}\text { Black to greenish black, hard shale enclosing } \\
\text { infrequent sandstone streaks. }\end{array}$ \\
\hline Lower Sandstone & Predominant sandstone with minor shale and silt. \\
\hline Lower Shale & Fissile shale with two discrete sandstone zones and negligible siltstone. \\
\hline
\end{tabular}

cases filtered to get rid of suspicious digitization errors. Since early time in petroleum industry, various methods and techniques have been introduced to calculate reservoir characteristics and the proper technique normally depends on the available data, reservoir conditions, and nature of the sedimentary units. Lithology, net/gross (N/G), clay volume, porosity, water saturation, net pay, and cut-offs are the main reservoir characteristics investigated in the present analysis. Figure 4 presents a flow chart for the methods applied in this study.

Typically two lithology models of multi minerals analysis, clastic and calcareous models, are utilized for lithological interpretation. Clastic model uses 


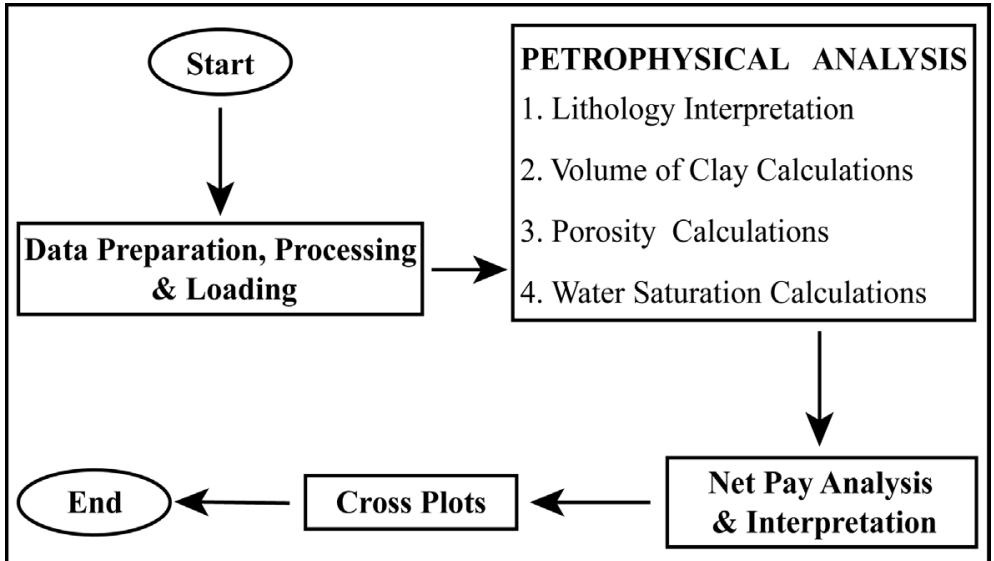

Figure 4. A flow chart showing the main steps of a standard petrophysical log analysis applied in the present study.

a mixture of sand, silt, and clay to characterize both argillaceous and arenaceous sediments while carbonate model is usually used to identify calcareous rock and evaporites together with clastic contents if present. Calcareous model is only applicable if sonic and photoelectric effect logs are available. In both models the available density, gamma ray, neutron, and resistivity logs are also used for lithology interpretation. Clay content can be calculated using gamma ray log, resistivity log, and/or a combination of neutron-density log [25]. All these models are investigated and gamma ray calculations are accepted to represent the actual clay content in the studied intervals. Larionov formula (Equations (1) and (2)) for pre-Tertiary rocks [26] is applied to quantify the clay content.

$$
\begin{gathered}
\mathrm{IGr}=\frac{\mathrm{Gr}-\mathrm{Gr} \text { clean }}{\text { Gr clay }-\mathrm{Gr} \text { clean }} \\
\mathcal{V}_{c \ell}=0.333\left(2^{2 \mathrm{IGr}}-1\right)
\end{gathered}
$$

where $\mathcal{V}_{C l}$ is the volume of clay, $\mathrm{Gr}$ is the gamma ray $\log$ reading of the Formation, Gr clean is the gamma ray matrix of clay free zone, and Gr clay is the gamma ray of the shale interval (100\% clay zone).

Since the presence of shale and gas severely influences the porosity calculations, the effective porosity of Zubair Formation can be calculated from the combination of density and neutron logs using both neutron and density porosity models. To start, the density porosity $\left(\phi_{D}\right)$ [27] and Neutron porosity $\left(\phi_{N}\right)$ [28] for the same interval is calculated and the results are subsequently used to define a mineral model. These mineral models help to obtain the corrected porosity ( $\phi$ ) using Equation (3).

$$
\phi=\phi_{D 1}+\frac{\phi_{N 1}-\phi_{D 1}}{1-\frac{\phi_{N 1}-\phi_{N 2}}{\phi_{D 1}-\phi_{D 2}}}
$$

where $\phi$ is the corrected porosity value, $\phi_{D 1}$ and $\phi_{N 1}$ are respectively the density and Neutron porosity corrected to matrix 1 , and $\phi_{D 2}$ and $\phi_{N 2}$ are respectively the 
density and Neutron porosity corrected for matrix 2.

To honor a particular model, several proposed methods have been tried to calculate water saturation $\left(S_{w}\right)$ in Zubair field. For flexibility and involving numerous parameters in calculations, the Indonesia equation is preferred to estimate effective water saturation in Zubair reservoirs. The basic Indonesia equation is presented in Equation (4) [29].

$$
\frac{1}{\sqrt{R_{t}}}=\left[\sqrt{\frac{\Phi^{m}}{a R_{w}}}+\frac{V_{c l}^{\left(1-\frac{v_{c l}}{2}\right)}}{\sqrt{R_{c l}}}\right] \cdot S_{w}^{n / 2}
$$

where $R_{c l}$ is the deep resistivity in clay zone (read from log), $R_{t}$ is the deep resistivity (read from $\log$ ), $R_{w}$ is the formation water resistivity (calculated using SP $\log$ ), $\Phi$ is the effective porosity, $S_{w}$ is the formation water saturation, ' $a$ ' is the tortuosity factor, ' $m$ ' is the cementation factor, and ' $n$ ' is the saturation exponent.

In Zubair field the default values of Archie parameters were set as $a=1.0, m=$ 1.6, and $n=2$. These preliminary values are changed using the built-in modules of IP software to facilitate accurate $S_{w}$ calculations at the various zones of both Zubair and Mishrif Formation. To delineate the net pay for Zubair field several porosity, water saturation, and clay content cut-off values have been tested. The optimum cut-off values that seem acceptable industry-wise reported $15 \%$ for porosity, $40 \%$ for formation water saturation, and $40 \%$ for shale volume cut-off. Such values wisely constrained the net pay zones for reservoir intervals with high potential to contain hydrocarbon. All calculations and analysis are completed using Interactive Petrophysics -IP V4.2 software [30].

\section{Results and Discussion}

Log data from seven wells producing from Mishrif Formation (Zb216, Zb225, $\mathrm{Zb} 280$, and Zb302) and Zubair Formation (Zb229, Zb278, and Zb309) (Figure 1 ) are numerically processed and verified consistent for petrophysical analysis. For each well, several petrophysical characteristics including porosity, water saturation, volume of clay, cut-offs, and net/gross are calculated and the full interpretation of each well is analyzed separately. Figure 5 and Figure 6 respectively present an example for the results of reservoir characteristics for carbonate facies in well $\mathrm{Zb} 216$ and clastic facies in well $\mathrm{Zb309}$ while cutoffs and pay results in well Zb216 are shown in Figure 7. For each pay zone or reservoir interval in any well, the statistical analysis provides a set of outputs including tabulated values, histograms, and cross plot for each property involved in reservoir characterization. The mean reservoir and pay parameters calculated in all wells tapping $\mathrm{Zu}-$ bair and Mishrif Formation are presented Table 2. In addition, an example of histograms constructed for average porosity $\left(\phi_{\text {avg }}\right)$, average water saturation $\left(\mathrm{Sw}_{\text {avg }}\right)$, and average volume of clay $\left(\mathrm{Vcl}_{\text {avg }}\right)$ in all reservoir intervals of $\mathrm{Zb} 216$ well is shown in Figure 8. The heterogeneity of reservoir characteristics in all zones are statistically evaluated using standard deviation and 


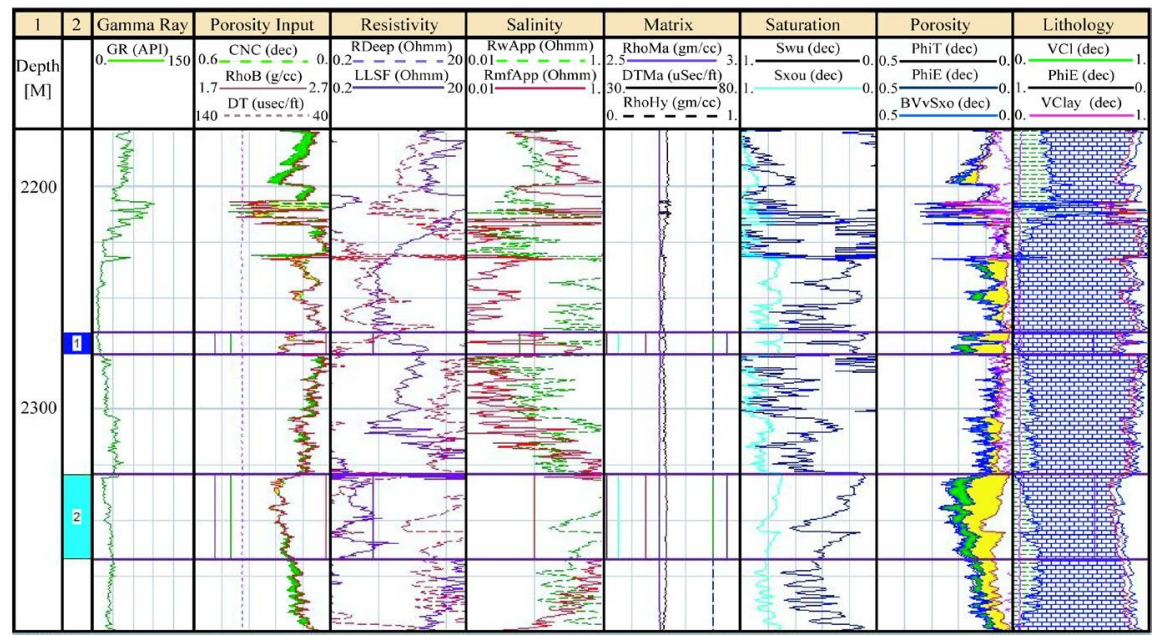

Figure 5. An example of log analysis in $\mathrm{Zb} 216$ well and the resulting carbonate facies of Mishrif Formation.

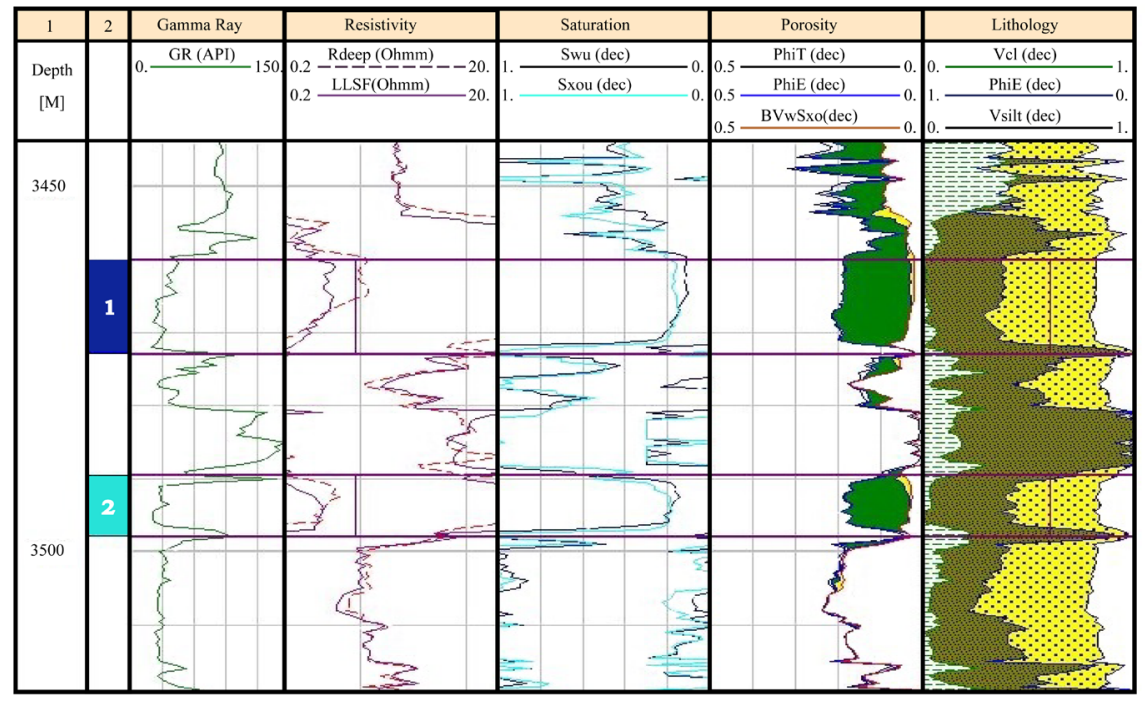

Figure 6. A sample of log analysis in Zb309 well and the resulting clastic facies of Zubair Formation.

the results are presented in Table 3.

\subsection{Petrophysical Characterization of Mishrif Formation}

Buday in [13] reported that Mishrif Formation is made of a complex of bioclastic detrital carbonates that can be simply discriminated into simple components using well log data. The present lithological and petrophysical analysis of Mishrif Formation indicated the development of two pay zones in $\mathrm{Zb} 216$ and $\mathrm{Zb302}$ wells (Figure 7 and Table 2) and three zones in Zb225 and Zb280 wells (Table 2). Generally, all these zones show clean formation with clay content between $2 \%$ and $10 \%$ with zone 2 and 3 showing a relatively close petrophysical values in all wells. Lithologically, all zones of Mishrif Formation are dominantly clean limestone and/or dolomitic limestone (Figure 5) with zones 2 and 3 reporting 


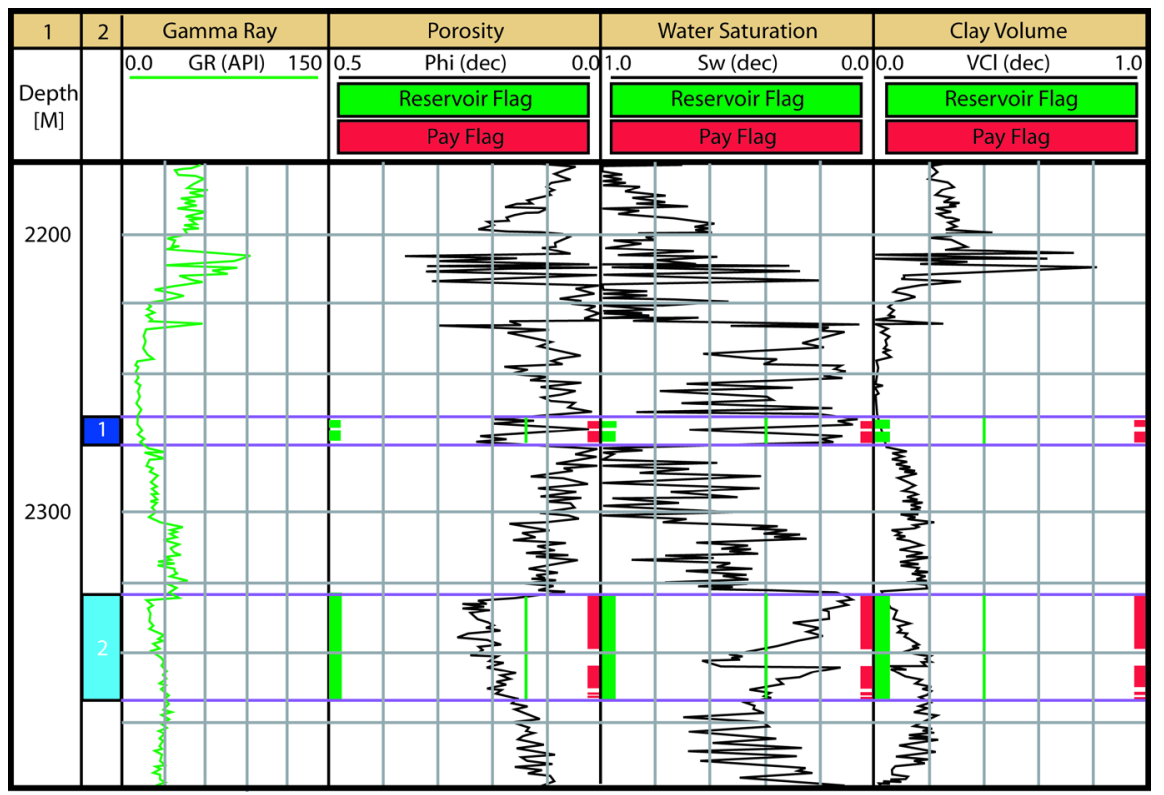

Figure 7. The pay results in Zb216 well.

Table 2. The mean reservoir parameters calculated for both reservoir and pay intervals in all wells.

\begin{tabular}{|c|c|c|c|c|c|c|c|c|c|c|c|c|}
\hline \multirow{2}{*}{ Fm. } & \multirow{2}{*}{ Well } & \multirow{2}{*}{ Zone } & \multirow{2}{*}{$\begin{array}{l}\text { Top } \\
\text { (m) }\end{array}$} & \multirow{2}{*}{$\begin{array}{c}\text { Bottom } \\
\text { (m) }\end{array}$} & \multicolumn{4}{|c|}{ Reservoir (decimal) } & \multicolumn{4}{|c|}{ Pay (decimal) } \\
\hline & & & & & $\mathrm{N} / \mathrm{G}$ & $\Phi_{\text {avg }}$ & Swavg & $\mathrm{Vcl}_{\text {avg }}$ & $\mathrm{N} / \mathrm{G}$ & $\Phi_{\text {avg }}$ & Swavg & $\mathrm{Vcl}_{\text {avg }}$ \\
\hline \multirow{10}{*}{ 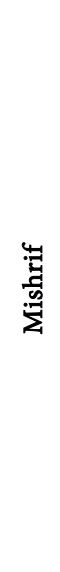 } & \multirow{3}{*}{$\mathrm{Zb} 216$} & 1 & 2265.5 & 2275.5 & 0.8 & 0.182 & 0.154 & 0.022 & 0.8 & 0.182 & 0.154 & 0.022 \\
\hline & & 2 & 2329.5 & 2367.5 & 0.974 & 0.186 & 0.273 & 0.118 & 0.763 & 0.189 & 0.216 & 0.1 \\
\hline & & 1 & 2206.5 & 2229.5 & 0.957 & 0.18 & 0.285 & 0.036 & 0.783 & 0.178 & 0.242 & 0.029 \\
\hline & \multirow[t]{3}{*}{$\mathrm{Zb} 225$} & 2 & 2244 & 2256.5 & 0.96 & 0.211 & 0.242 & 0.05 & 0.92 & 0.212 & 0.236 & 0.047 \\
\hline & & 3 & 2298 & 2328 & 1 & 0.24 & 0.284 & 0.101 & 0.85 & 0.245 & 0.26 & 0.09 \\
\hline & & 1 & 2490 & 2508 & 0.972 & 0.211 & 0.418 & 0.124 & 0.903 & 0.215 & 0.397 & 0.114 \\
\hline & \multirow[t]{2}{*}{$\mathrm{Zb} 280$} & 2 & 2549.5 & 2593 & 1 & 0.231 & 0.511 & 0.05 & 0.563 & 0.241 & 0.418 & 0.047 \\
\hline & & 3 & 2597 & 2603.5 & 1 & 0.199 & 0.502 & 0.148 & 0.615 & 0.207 & 0.416 & 0.118 \\
\hline & \multirow{2}{*}{ Zb302 } & 1 & 2550 & 2570.5 & 0.951 & 0.207 & 0.451 & 0.101 & 0.732 & 0.214 & 0.4 & 0.095 \\
\hline & & 2 & 2576.5 & 2599 & 0.889 & 0.18 & 0.427 & 0.141 & 0.733 & 0.181 & 0.403 & 0.138 \\
\hline \multirow{4}{*}{ 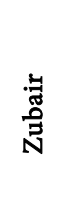 } & Zb229 & 1 & 3277.5 & 3298.5 & 0.905 & 0.206 & 0.159 & 0.017 & 0.881 & 0.207 & 0.153 & 0.017 \\
\hline & Zb278 & 1 & 3358 & 3384 & 0.923 & 0.22 & 0.216 & 0.033 & 0.856 & 0.222 & 0.194 & 0.031 \\
\hline & \multirow{2}{*}{ Zb309 } & 1 & 3460 & 3473 & 0.905 & 0.192 & 0.161 & 0.019 & 0.865 & 0.194 & 0.149 & 0.019 \\
\hline & & 2 & 3489.5 & 3498 & 0.765 & 0.173 & 0.191 & 0.028 & 0.765 & 0.173 & 0.191 & 0.028 \\
\hline
\end{tabular}

higher dolomitic content (20\% to $40 \%$ ) compared to the lower dolomite content in zone 1 ( $6 \%$ to $13 \%$ ). This observation may explain the relatively higher porosity in zones 2 and 3 compared to zone 1 in Zb216 and Zb225 wells (Table 2). Petrophysical analysis indicated a relatively good porosity $(18 \%-24 \%)$ in all pay zones of Mishrif Formation (Table 2). In most cases, the average porosity of zone $1(17.8 \%$ 


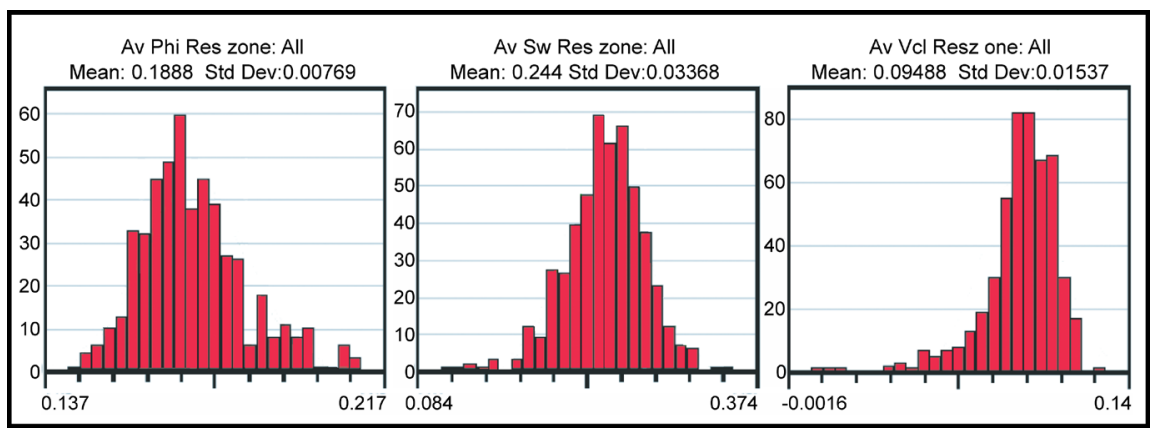

Figure 8. The histograms of $\phi_{\text {avg }}$ (left), $\mathrm{Sw}_{\text {avg }}$ (middle) and $\mathrm{Vcl}_{\text {avg }}$ (right) in all reservoir intervals of $\mathrm{Zb} 216$ well.

in $\mathrm{Zb} 225$ well and 21.4 in $\mathrm{Zb} 302$ well) is slightly lower than the corresponding values in zones 2 and 3 (18.1 and $\mathrm{Zb} 302$ well and 24.5 in $\mathrm{Zb} 225$ well).

Appraising the variation in porosity through the wells penetrating Mishrif Formation indicated some comparatively moderate fluctuations through the pay zones that in most cases do not exceed 5\%. The average porosity in zone 1 (Table 2) shows a comparable result to the clay content shown in Figure 5. Alternatively, the average porosity in zone 2 showed a moderate increase in the average calculated porosity from $19 \%$ to approximately $24 \%$ (Table 2). Such a trend does not have any obvious relation to the clay content in zone 2 indicating that the porosity estimate of zone 2 in Mishrif Formation is independent to clay content and predominantly related to secondary porosity associating dolomitization processes. Aqrawi et al. in [8] marked early diagenetic microfacies as poring in planktonic foraminifera and/or occasional pyrite crystals while cloudy-centered dolomite rhombs indicate later burial diagenesis. Typically, the upper parts of the basin are strongly affected by meteoric near-surface diagenesis. Alternatively, mixing-zone diagenesis in mudstone and wackestone of intertidal flats is identified by dolomite rhombs [31] [32]. The presence of vugs, channel porosity or other dissolution features can be attributed to meteoric phreatic diagenesis [33]. Generally, porosity of all zones in wells tapping Mishrif Formation shows considerable homogeneity as indicated by a standard deviation less than 1 porosity unit except for $\mathrm{Zb} 280$ well that develop as standard deviation of 4.1 porosity units.

Average water saturation ( $\left.\mathrm{Sw}_{\text {avg }}\right)$ in the two zones of Mishrif Formation varies dramatically among the studied wells with minimum of 0.15 in Zb2016 well and maximum of 0.551 in $\mathrm{Zb} 280$ well (Table 2). Generally, the $S_{\mathrm{w}}$ distribution in both zones follows the common trends of clay content distribution indicating an apparent effect of clay content on $S_{w}$ calculations. Among the studied wells, $\mathrm{Zb} 216$ and Zb225 wells showed a comparatively lower $S_{\mathrm{w}}$ values $(\sim 0.23)$ compared to the consistent $\mathrm{S}_{\mathrm{w}}$ values $(\sim 0.41)$ calculated in $\mathrm{Zb} 280$ and $\mathrm{Zb} 302$ wells. The variations in calculated $S_{w}$ had a standard deviation between $3 \%$ and $4 \%$ in all wells, but such value dramatically increased to over $10 \%$ in $\mathrm{Zb} 280$ well. This effect could be attributed to the diagenetic effect fostered by the relative increase in shale content. The calculated volume of clay in Mishrif Formation hardly ex- 
ceeds $10 \%$ for both reservoir and pay intervals indicating clean formation (Table 2 and Table 3). Characterizations of net pay zones within the gross reservoir intervals of Mishrif Formation showed a good N/G ratio with a minimum value of 0.47 reported in zone 2 of $\mathrm{Zb} 280$ and a maximum value of 0.83 calculated in zone 2 of $\mathrm{Zb} 225$ well. In general, zone 1 of Mishrif shows a relatively consistent $\mathrm{N} / \mathrm{G}$ values $(\sim 0.65)$ in the majority of wells compared to zone 2 that reported the maximum and minimum values observed in Mishrif Formation (Table 2). Generally, N/G calculations showed moderate standard deviation that falls dominantly below $20 \%$ but such value increased to $27 \%$ in $\mathrm{Zb} 302$ well due to the effect of shale. The present analysis had no evidence of an obvious oil-water contact in the studied wells of Mishrif Formation, indicating the absence of aquifer or at least a strong aquifer (Figure 5). Due to the lack of seismic data and subsurface maps for Zubair field, it was difficult to infer the reservoir boundaries or the spatial extension of the identified pay zones.

\subsection{Petrophysical Characterization of Zubair Formation}

Pay analysis in Zubair Formation indicated the presence of only one pay zone in Zb229 and Zb278 wells and two zones in Zb309 well only (Figure 6). Generally, the relative sand content of these zones falls between $72 \%$ (Zb278 well, located northward) and 62\% (Zb309 well located southeast) but the silt content follows the opposite trend with average silt content between 25\% (Zb278 well) and 35\% (Zb309 well). This increase in silt is more obvious in zone 2 and therefore the N/G ratio is considerably low (0.65) compared to that of zone $1(\sim 0.83)$. This fact is also presented by higher standard deviation in Zb309 well that shows double the value reported in $\mathrm{Zb} 229$ well (Table 3). In addition, the clay content of all pay zones in Zubair Formation is generally low with average content between $2 \%$ and $3 \%$. Such clean facies is supportive to the interpretation of the littoral to near shore depositional environment [34]. The average porosity of $\mathrm{Zu}$ bair pay zones in the studied wells showed slightly better values in zone 1 $(\sim 0.20)$ compared to the average porosity of zone $2(0.17)$ (Table 2$)$. The change in porosity of the two zones is attributed to the higher silt content of zone 2 associating deposition at relatively deeper parts of the shelf. This pattern is closely similar to the lithostratigraphic log characteristics recognized by Ali and Nasser in [21] in Zubair Formation of Southern Iraq, where the silt content characterized the sand package into two members; clean upper member and silty lower member. Generally, the porosity of Zubair Formation shows an obvious oscillating pattern at the upper part (Figure 6) while the lower part that encompasses the pay zones is marked by a relatively stable porosity pattern. This pattern markedly changes southward at Zb309 well where the oscillating part is warped to a minimal thickness in the studied wells. However, this well reported a higher standard deviation compared to the other wells of Zubair Formation (Table 3).

The presence of laminated clay in sand is usually problematic for petrophysical analysis due to its ability to mask out the hydrocarbon zones by inducing lower Rt measurements. The average water saturation in the pay zones of Zubair 
field show distinct lower values that varies between $15 \%$ in $\mathrm{Zb} 229$ and $\mathrm{Zb} 309$ wells to $18.7 \%$ in $\mathrm{Zb} 278$ well (Table 2). These values usually match the typical connate water values in most hydrocarbon reservoirs. Compared to zone 1 , zone 2 shows slightly higher $S_{w}$ values (20\%) that is probably related to the nature of the fine-grained facies developed in Zone 2 (Figure 6). Careful analysis indicates the presence of well-developed aquifer system beneath the pay zones that could be masked by a thin barrier (e.g. Figure 6). This interpretation is based on the higher calculated $S_{w}$ associating higher porosity values with minimal clay content.

\subsection{Cross Plots}

As a powerful mean to investigate the mutual relationship between two independent reservoir properties, cross plots for any couple of reservoir or pay characteristics are tested to help inferring a possible relationship. In the present work 4 cross plots ( $S_{w}$ vs Vclay, $\phi$ vs Vclay, $\phi$ vs $S_{w}$, and N/G vs $S_{w}$ ) have been constructed. As an example for such cross plots, Figure 9 shows the Vclay, $S_{w} \phi$, N/G cross plots for all pay intervals in Zb216 well. Generally, $S_{w}$ vs Vclay cross plot

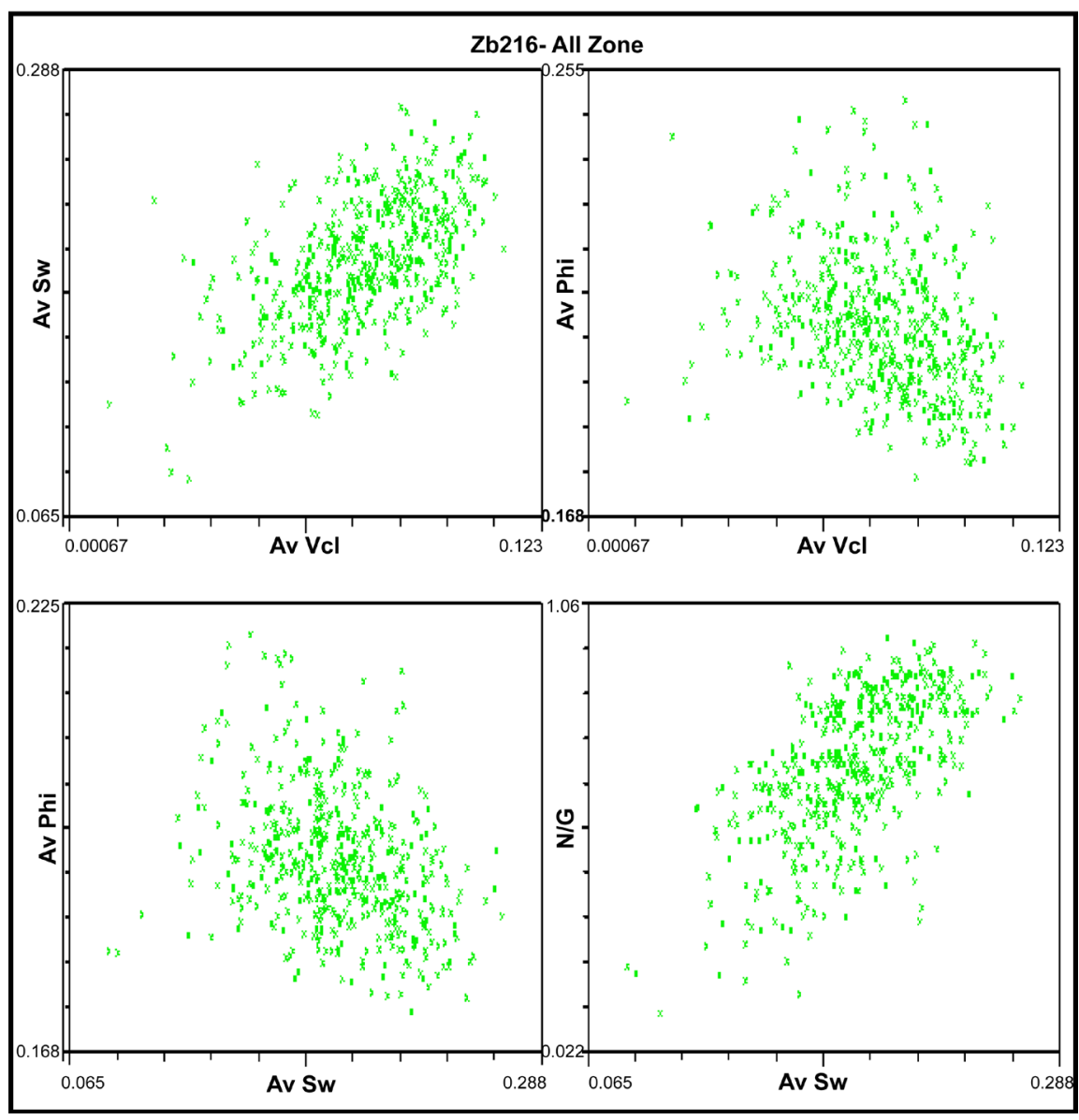

Figure 9. The cross plots for average values of $S_{w}$ versus Vclay (upper left), $\phi$ versus Vclay (upper right), $\phi$ versus $S_{W}$ (lower left) and N/G versus $S_{W}$ (lower right) for all pay intervals in $\mathrm{Zb} 216$ well. 
Table 3. The standard deviation of reservoir parameters calculated in all zones of reservoir and pay intervals of Zubair and Mishrif Formations.

\begin{tabular}{|c|c|c|c|c|c|c|c|c|c|}
\hline \multirow{2}{*}{ Formation } & \multirow{2}{*}{ Well } & \multirow{2}{*}{ Zones } & \multicolumn{3}{|c|}{ Reservoir } & \multicolumn{4}{|c|}{ Pay } \\
\hline & & & Phi & $S_{w}$ & $\mathrm{Vcl}$ & Phi & $S_{W}$ & $\mathrm{Vcl}$ & $\mathrm{N} / \mathrm{G}$ \\
\hline \multirow{4}{*}{ 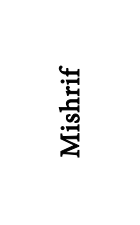 } & $\mathrm{Zb} 216$ & All & 0.8 & 3.4 & 1.6 & 0.8 & 2.9 & 1.8 & 15.4 \\
\hline & $\mathrm{Zb} 225$ & All & 0.9 & 3.1 & 2.0 & 1.1 & 3.5 & 2.2 & 19.9 \\
\hline & $\mathrm{Zb} 280$ & All & 4.1 & 10.5 & 3.7 & 4.6 & 12.9 & 3.0 & 2.8 \\
\hline & Zb302 & All & 0.9 & 4.1 & 5.1 & 1.4 & 4.8 & 5.0 & 27.2 \\
\hline \multirow{3}{*}{ 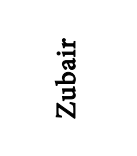 } & Zb229 & All & 0.6 & 2.3 & 0.7 & 0.6 & 2.1 & 0.7 & 8.2 \\
\hline & $\mathrm{Zb} 278$ & All & 0.7 & 2.9 & 0.8 & 0.7 & 2.6 & 0.8 & 11.8 \\
\hline & Zb309 & All & 1.5 & 4.5 & 1.1 & 1.5 & 4.5 & 1.1 & 16.5 \\
\hline
\end{tabular}

shows widely scattered points in most wells but shows a noisy direct relation in Zb278 well. This may indicate that $S_{w}$ and Vclay calculations are independent in most wells. A similar relation is visualized in $\phi$ vs $S_{w}$ cross plot as indicated by the scattered points (Figure 9) but in Zb302 and Zb278 wells a marginally negative relationship can hardly be depicted. On the other hand, the $\phi$ vs Vclay cross plot shows an obvious inverse relationship that disagrees with typical positive relationships in most reservoirs. This can be explained in the context of the mode of shale occurrence as in the present case may constitute minute particulates occupying part of the pore space within the pay zone. The N/G- $S_{w}$ cross plot shows a direct relation in most wells but such a relation was slightly obscured in Zb229 and Zb278 wells indicating large changes in $S_{w}$ values within these wells. Among the studied wells, Zb309 well showed a small range of $S_{W}$ that lead to false relations.

\section{Conclusions}

Zubair field produces oil from two packages; Mishrif Formation normally encountered at the depth of $2200-2600 \mathrm{~m}$ and Zubair Formation located at the depth of $3000-3600 \mathrm{~m}$ below land surface. The lithological and petrophysical analysis of log data in wells penetrating Mishrif Formation indicated the development of two pay zones in two wells, and three zones in the other two wells. Generally, all zones of Mishrif Formation are dominantly clean to dolomitic limestone with zones 2 and 3 reporting higher dolomitic content (20\% to 40\%) compared to low dolomite content in zone 1 (6\% to 13\%). Petrophysical analysis indicated a relatively good porosity $(18 \%-24 \%)$ in the pay zones of Mishrif Formation with zone 2 predominantly related to secondary porosity associating the diagenetic history. Characterizations of net pay zones within the gross reservoir intervals of Mishrif Formation showed a good N/G ratio with the minimum value of 0.47 and maximum value of 0.83 .

Lithological interpretation of well log data of three wells in Zubair Formation indicated the presence one pay zone in two wells and two zones in one well. The 
clay content of all pay zones in Zubair Formation is generally low with the average content between $2 \%$ and $3 \%$. The average porosity of Zubair pay zones in the studied wells showed slightly better values in zone $1(\sim 0.20)$ compared to average porosity of zone $2(0.17)$. The change in porosity of the two zones is attributed to the higher silt content associating deposition at relatively deeper parts of the shelf. The average water saturation in the pay zones of Zubair Formation shows distinct lower values that vary between $15 \%$ and $18.7 \%$. Careful analysis for the petrophysical characterization results of Zubair Formation indicates the presence of well-developed aquifer system beneath the pay zones that could be masked by a thin barrier. Such interpretation is disputable and may disagree with the impression of the operating company that assumes deficiency of aquifer support in Zubair field.

\section{Acknowledgements}

The Authors acknowledge and appreciate very much the Southern Petroleum Company (Basrah, Iraq) for providing the technical support and well log data. Many thanks to Prof. Dr. Selim Zidan, Petroleum Engineering Department of Al Azhar University and Prof. Dr. Abdel Zaher Abu Zaid from Mining, Petroleum, and Metallurgical Engineering Department of Cairo University for the fruitful comments and initial drafting work.

\section{References}

[1] Amaefule, J.O., Kersey, D.G., Marshall, D.M., Powell, J.D., Valencia, L.E. and Keelan, D.K. (1988) Reservoir Description: A Practical Synergistic Engineering and Geological Approach Based On Analysis of Core Data. SPE-18167-MS, SPE Annual Technical Conference and Exhibition, Houston, 2-5 October. https://doi.org/10.2118/18167-MS

[2] Harris, P.M., Frost, S.H., Seiglie, G.A. and Schneidermann, N. (1984) Regional Unconformities and Depositional Cycles, Cretaceous of the Arabian Peninsula. In: Schlee, J.S., Ed., Interregional Unconformities and Hydrocarbon Accumulations. AAPG Memoir, 36, 67-80.

[3] Sneider, R.M., King, H.R., Hawkes, H.E. and Davis, T.B. (1983) Methods for Detection and Characterization of Reservoir Rock, Deep Basin Gas Area, Western Canada. Journal of Petroleum Technology, 35, 1725-1734. https://doi.org/10.2118/10072-PA

[4] Worthington, P.F. and Cosentino, L. (2005) The Role of Cut-Offs in Integrated Reservoir Studies. SPE Reservoir Evaluation \& Engineering, 8, 276-290. https://doi.org/10.2118/84387-PA

[5] Jassim, S.Z. and Goff, J.C. (2006) The Geology of Iraq. Dolin Publishing, Czech, 341.

[6] Mazeel, M.A. (2012) Hydrocarbon Reservoir Potential Estimated for Iraq Bid Round Blocks. Oil and Gas Journal, 110, No. 3.

[7] Aqrawi, A.A.M., Goff, J.C., Horbury, A.D. and Sadooni, F.N. (2010) The Petroleum Geology of Iraq. Scientific Press, Cambridge, 424.

[8] Aqrawi, A.A.M., Thehni, G.A., Sherwani, G.H. and Kereem, B.M.A. (1998) MidCretaceous Rudist-Bearing Carbonates of the Mishrif Formation; An Important 
Reservoir Sequence in the Mesopotamian Basin. Journal of Petroleum Geology, 21, 57-82. https://doi.org/10.1111/j.1747-5457.1998.tb00646.x

[9] Gaddo, J.Z.H. (1971) The Mishrif Formation Palaeoenvironment in the Rumaila/Tuba/Zubair Region of South Iraq. Journal of the Geological Society of Iraq, 4, 1-12.

[10] Reulet, J. (1982) Carbonate Reservoir in a Marine Shelf Sequence, Mishrif Formation, Cretaceous of the Middle East. In: Reeckman, A. and Friedman, G.M., Eds, Exploration for Carbonate Petroleum Reservoirs. John Wiley, New York, 165-173.

[11] Al-Khadhimi, J.A., Sissakian, V.K., Falah, A.S. and Deikran, D.B. (1996) Tectonic Map of Iraq (Scale 1: 1000000). S.E. of Geological Survey and Mining, Iraq.

[12] Al-Sakini, J. (1992) Summary of Petroleum Geology of Iraq and the Middle East. Internal Report in Arabic, Northern Petroleum Company, Kirkuk, 179 p.

[13] Buday, T. (1980) The Regional Geology of Iraq Vol. 1, Stratigraphy and Palaeogeography. Dar Al-Kutub Publication House, Mosul, 445 p.

[14] Al-Ameri, T.K., Jafar, M.S. and Pitman, J. (2011) Hydrocarbon Generation Modeling of the Basrah Oil Fields, Southern Iraq. APG Search and Discovery Article 90141, GEO-2012, 10th Middle East Geosciences Conference and Exhibition, Manama, 4-7 March 2012.

[15] Al-Ekabi, A.H.S. (2015) Microfacies and Environmental Study of the Mishrif Formation in Noor Field. Arabian Journal of Geosciences, 8, 5779-5794. https://doi.org/10.1007/s12517-014-1589-2

[16] Bellen, R.C., vanDunnington, H.V., Wetzel, R. and Morton, D.M. (1959) Iraq: LexiqueStrat. Internat. Centre Nat. Rech. Scientifique, III, Asie, Fasc.10a, Paris, 333 p.

[17] Burchette, T.P. (1993) Mishrif Formation (Cenomanian-Turonian), Southern Arabian Gulf: Carbonate Platform Growth along a Cratonic Basin Margin. In: Simo, J.A.T., Scott, R.W. and Masse, J.-P., Eds., Cretaceous Carbonate Platforms, Am. Assoc. Petrol. Geol. Mem. 56, Chapter 16, 185-200.

[18] Al-Dabbas, M., Al-Jassim, J. and Al-Jumaily, S. (2010) Depositional Environments and Porosity Distribution in Regressive Limestone Reservoirs of the Mishrif Formation, Southern Iraq. Arabian Journal of Geosciences, 3, 67-78. https://doi.org/10.1007/s12517-009-0057-x

[19] Al-Siddiqi, A.A.M. (1978) Subsurface Geology of Southeastern Iraq. 10th Arab. Pet. Cong., Tripoli-Libya, Paper No. 141 (B-3), 47.

[20] Aqrawi, A.A.M., Mahdi, T.A., Sherwani, G.H. and Horbury, A.D. (2010) Characterization of the Mid-Cretaceous Mishrif Reservoir of the Southern Mesopotamian Basin, Iraq. AAPG Search and Discovery Article 50264.

[21] Ali, A.J. and Nasser, M.E. (1989) Facies Analysis of the Lower Cretaceous Oil-Bearing Zubair Formation in Southern Iraq. Modern Geology, 13, 225-242.

[22] Al Rawi, M.M. (1981) Geological Interpretation of Oil Entrapment in the Zubair Formation, Raudhatain Field. 2nd SPE Middle East Oil Show, Bahrain, SPE 9591, 149-158. https://doi.org/10.2118/9591-MS

[23] Owen, R.M.S. and Nasr, S.N. (1958) Stratigraphy of the Kuwait-Basrah Areas. In: Weeks, L.G., Ed., Habitat of Oil, a Symposium, Am. Assoc. Petrol. Geol., 1252-1278.

[24] Al-Jubory, L.J. (2005) Sedimentology and Reservoir Properties of the Upper Sand Member of Zubair Formation in Southern Rumailah Oil Field, South of Iraq. M.Sc. Thesis in Arabic, Baghdad University, 162 p.

[25] Ellis, D.V. and Singer, J.M. (2007) Well Logging for Earth Scientists. Vol. 692, Springer, Dordrecht. 
[26] Larionov, V.V. (1969) Borehole Radiometry Moscow, U.S.S.R. In: Nedra, M.R.L. and Biggs, W.P., Eds., Using Log-Derived Values of Water Saturation and Porosity, Trans. SPWLA Ann. Logging Symp. Paper, 10, 26.

[27] Bertozzi, W., Ellis, D.V. and Wahl, J.S. (1981) The Physical Foundations of Formation Lithology Logging with Gamma Rays. Geophysics, 46, 1439-1455. https://doi.org/10.1190/1.1441151

[28] Pillai, P., Boyle, K., Toumelin, E. and Kho, D. (2015) Advanced Formation Logging: A Case Study of Revealing the True Potential of a Gas Reservoir. SPWLA 56 Annual Logging Symposium, Long Beach, 18-22 July 2015.

[29] Schlumberger (2008) Interactive Petrophysics Version 3.5 User's Manual. Senergy Ltd., Banchory.

[30] Schlumberger (2013) Interactive Petrophysics Help Version 4.2 User's Manual. Senergy Software Ltd., Banchory.

[31] Badiozamani, K., Mackenzie, F.T. and Thorstensen, D.C. (1977) Experimental Carbonate Cementation: Salinity, Temperature and Vadose-Phreatic Effects. Journal of Sedimentary Petrology, 47, 529-542.

[32] Aqrawi, A.A.M. (1995) Brackish Water and Evaporite Ca-Mg Carbonates in the Miocene Lacustrien/Deltaic Deposits of Southern Mesopotamia. Journal of the Geological Society, 152, 259-268. https://doi.org/10.1144/gsigs.152.2.0259

[33] Longman, M.W. (1982) Carbonate Diagenesis as a Control on Stratigraphic Traps. AAPG Education Course Series, 21, 159 p.

[34] Abdullah, E.H.A. and Kinghorn, R.R.E. (1996) A Preliminary Evaluation of Lower and Middle Cretaceous Source Rocks in Kuwait. Journal of Petroleum Geology, 19, 461-480. https://doi.org/10.1111/j.1747-5457.1996.tb00450.x 